\title{
Sarab Stroumsa
}

\section{Ibn Masarra and the Beginnings of Mystical Thought in al-Andalus*}

Some of the crucial stages in the development of both Jewish and Christian mysticism have taken place in the Iberian peninsula. Suffice it to mention the Zohar on the one hand, Teresa of Avila and John of the Cross on the other. That the emergence and development of mystical systems of both religions in Spain justifies a comparative study seems almost obvious. But no such study would be completein fact, no such study would be likely to offer a balanced or correct historical insight - without it including also Muslim Andalusian mysticism. Miguel Asín $\mathrm{Pa}$ lacios has forcefully argued for the relationship between Christian and Islamic mystics. Asín saw the roots of the Carmelite renunciation of carismata in the teaching of the Muslim mystic Ibn 'Abbād of al-Rondā (d. 1389) ${ }^{1}$. Asín was also sensitive to Jewish-Muslim connections, but he did not dwell on their existence in the domain of mysticism, but rather in that of Neo-Platonist philosophy. In particular, he was fascinated by what he considered to be the doctrine of Pseudo-Empedocles. The search for the teachings of Pseudo-Empedocles and for his "Book of Five Substances" had begun already with David Kaufmann ${ }^{2}$ and Solomon Munk $^{3}$, but it was mostly Asín who developed the theory of a school of thought whose hallmark is the doctrine of Pseudo-Empedocles ${ }^{4}$. Asín based his theory on the similarities in the thought of some Neo-Platonist thinkers, from the tenth century Muslim Ibn Masarra to the eleventh century Jew Ibn Gabirol, and up to the fifteenth century kabbalistic texts such as Elhanan ben Abraham's Yesod Olam, and Latin Neoplatonism in Christian Europe ${ }^{5}$.

* The research for this study was prepared in 2002-2003, during a year at the Institute of Advanced Studies of the Hebrew University of Jerusalem. I wish to extend my thanks to the Institute and to my colleagues there. In particular, I am indebted to Sara Sviri, for her helpful comments on a previous draft of this paper.

1 Miguel Asin Palacios, Un precursor hispanomusulman de San Juan de la Cruz, in: Al-Andalus 1 (1933) 7-79; reprinted in: Idem, Obras Escogidas, I (Madrid 1946) 246-326.

2 D. Kaufmann, Studien über Salomon ibn Gabirol (Budapest 1899) 13-71.

3 S. Munk, Mélanges de philosophie juive et arabe (Paris 1859; reprinted Paris 1988).

4 Miguel Asín Palacios, Abenmasarra y su escuela (Madrid 1914) (The Mystical Philosophy of Ibn Masarra and his Followers, translated by E. H. Douglas and H. W. Yoder [Leiden 1978]).

5 For the history of the theory, see D. De Smet, The Influence of the Arabic Pseudo-Empe- 
Asin, who called this stream of thought "the school of Ibn Masarra", relied on secondary sources - the only ones available to him then. In what follows I will focus on the figure of Ibn Masarra and attempt to identify his intellectual affinities as reflected in his own writings. I will then point to the existence of some elements in his writings which appear to have Jewish connotations; and finally, I will examine the possible implications of these elements for the evaluation of the Jewish role in the formation of mystical and Neo-Platonist thought in the Iberian peninsula.

Very little is known concerning the early stages of the introduction of speculative thought into al-Andalus. An illustration of the thick fog that covers these beginnings can be furnished by the tenth century enigmatic figure of Ibn Masarra. The enigma is not caused by the lack of biographical information, which, despite some moot points, allows us to trace his life. Muhammad b. 'Abdallāh al-Jabalī, known as Ibn Masarra, was born in Cordoba in 883 C.E. His father 'Abdallāh had traveled to the east, had been to Basra, where he is said to have studied with Mu'tazili theologians, and died in Mecca. Muhammad Ibn Masarra himself also went to Mecca, via Kairouan ${ }^{6}$. He returned to al-Andalus during the reign of ${ }^{e} \mathrm{Abd}$ al-Raḥmān III al-Nāṣir (912-962) where he died around the year $931^{7}$.

What remains enigmatic, however, is the nature of Ibn Masarra's teaching. Miguel Cruz Hernández describes him as "the first Spanish-born Muslim thinker of some originality" 8 . But the question arises, what kind of a thinker? Ibn Masarra seems to be everything to everyone. The Muslim historiographers describe him as

docles on Medieval Latin Philosophy: Myth or Reality, in: D. A. Agius and I. R. Netton (eds.), Across the Mediterranean Frontiers: Trade, Politics and Religion, 650-1450 (Turnhous 1997) 225-234; idem, Empedocles Arabus. Une lecture néoplatonicenne tardive (Brussel 1998) 15-17.

6 See notes 28 and 79 below.

7 For a general overview of Ibn Masarra, his biography and the sources about him, see Asin Palacios, The Mystical Philosophy of Ibn Masarra; E. Lévi-Provençal, A propos de l'ascètephilosophe Ibn Masarra de Cordoue, in: Orientalia Suecana III (Donum Natalicium H. S. Nyberg Oblatum, Uppsala 1954) 75-83; M. A. Makki, Ensayo sobre las aportaciones orientales en la España musulmana y su influencia en la formación de la cultura hispano-árabe (Madrid 1968) 155-162; Mubammad Kamāl Ibrāhìm Jáfar, Min qadāyā al-fikr al-islāmì, dirāsa wa-nuṣuṣ (Cairo 1976; henceforward: Ja'far, Min qad̄āyā) 182-221; L. E. Goodman, Ibn Masarrah, in: S. H. Nasr and O. Leaman (eds.), History of Isalmic Philosophy, vol. I (London, New York 1996) 277-293; D. Urvoy, Sur les débuts de la pensée spéculative en Andalus, in: Mélanges de l'Université Saint-Joseph 50 (1984) 707-717; R. Arnaldez, Ibn Masarra, in: Encyclopedia of Islam, New Edition (henceforward: EI ${ }^{2}$ ), Vol. III (Leiden, London 1986) 868-872; M. Cruz-Hernández, Historia del pensamiento en el mundo islámico, vol. 2: El pensamiento de al-Andalus (siglos IX-XIV) (Madrid 19962) 344-357; E. Tornero Poveda, La Filosofía, in: El retroceso territorial de Al-Andalus. Almorávides y almohades, Siglos XI al XIII, vol. 8:2 of Historia de España fundada por R. Menéndez Pidal y dirigida por J. M. Jover Zamora, coord. por M.J. Viguera (Madrid 1997) 587-602, on 589-590.

8 El pensamiento de al-Andalus 344 (“... el primer pensador musulmán muladī con ideas en cierto modo originales"). A similar appreciation (with similar reserve) is implied by LéviProvençal, who describes Ibn Masarra as "the initiator of the force of philosophical speculation and of a movement of ideas," cf. E. Lévi-Provençal, Historia de la España musulmana - La vida religiosa e intelectual 309-321, on 314. 
a recognized legal authority $\left(f_{a q i}{ }^{9}\right)^{9}$. But they also say other things about him, which suggest more philosophical interests: that he held views close to those of the Muetazila ${ }^{10}$; it is insinuated that he made use of [Aristotelian?] logic ${ }^{11}$; that he withdrew with his adepts to a retreat in the Cordobese Sierra ${ }^{12}$, where he led an ascetic life; that he was a $b \bar{a} t i n \bar{\imath}^{-13}$, an ambiguous term that may indicate either șūfī or ismaili affiliations ${ }^{14}$. As a source for his thought we find mentioned his own travels to the east (as well as those of his father), with possible encounters with mu'tazili scholars ${ }^{15}$. But he is also said to have met sunfī masters, and to have been influenced by the thought of early Muslim sufis, such as al-Junayd, Dhū al-Nūn al-Mișrī, and Sahl al-Tustarī.

The seemingly contradictory information provided by medieval Muslim historiographers is reflected in modern scholarship, where much speculation has been published concerning Ibn Masarra's philosophical tendency. He is variously described as a Mu'tazili theologian'16, a mystic ${ }^{17}$, a Neo-Platonist philosopher

$9 \mathrm{He}$ is thus introduced in the title of one his works in the unique manuscript (but see note 13 below); cf. Chester Beatty Library, Ar. 3168, fol. 175 (Henceforward: D); Jafar, Min qadāya, 348). I wish to express my thanks to the Chester Beatty Library in Dublin for the permission to use the manuscript, and to Prof. David Wasserstein, for his help in procuring it.

According to Ibn Hayyān, Ibn Masarra was versed in the basic Mālikī code of law, the $m u$ dawwana; cf. P. Ch́almeta et al. (eds.), Al-Muqtabas [V] de Ibn Hayyān (Madrid 1979) $20 \mathrm{ff}$.

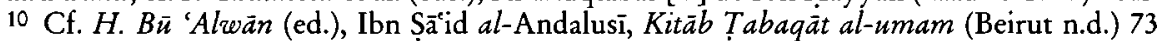
(regarding his views on the divine attributes); Al-Muqtabas V 27 (regarding the accusation of Ibn Masarra's followers of adhering to the doctrine of the created Qur'ãn).

11 This seems to be the insinuation of Ibn Hayyān, who accuses Ibn Masarra of crafty use of mantiq; cf. Al-Muqtabas V. $20 \mathrm{ff}$.

12 It is interesting to note that according to Takmila p. 339, this Cordoban retreat was a replica of the house of Māriya, the Prophet's Christian concubine, in Medina; cf. Asin Palacios, The Mystical Philosophy 38.

${ }^{13} \mathrm{Cf}$. Ibn Să $\bar{a}^{-\mathrm{id}}, 73$. On the title page of another work of Ibn Masarra, he is introduced as " $a$ shaykh al-'ärif al-mubaqqiq", thus indicating his association with șūfī gnosis; cf. D fol. 129; Jafar, Min qadàyā, 310-311.

14 On the meaning of this term, see further below. Al-Wansharisi (al-Micyar, X [Fez 1897] 443-444, accuses Ibn Masarra's followers of shiite ("rafidite") affiliations; cf. M. Fierro, "Los Mālikies de al-Andalus y los dos árbitros (al-bakamān), in: Al-Qantara 6 (1985) 79-102.

15 Ibn Hayyān (Muqtabas 32) says (citing Ta'rikh al-'ulamä') that Ibn Masarra was "known to uphold a mu'tazili doctrine" (mairu $f b i$-madhhab min al-i $i^{e} t i z \bar{a} l$ ) and that he had spent time in the encounters with mutazili diaclectic theologians, heresiographers and polemicists (wa-'ishtaghala bi-mulāqāt al-mutakallimin wa-aṣ̂āb al-maqālāt wa-ahl al-jadal min al-mu'tazila). The credibility of the accusation of mutazilite inclinations diminishes when the author continues to say that "he demonstrated asceticism, piety, and withdrawal from people's company" (ítizālan li'l-nās).

16 Cf., for instance, M. Fierro, Heresy in al-Andalus, in: S. K. Jayyusi (ed.), The Legacy of Muslim Spain (Leiden 1992) 895-908, on 900 (regarding Ibn Masarra's youth); E. Tornero, Nota sobre el pensamiento de Abenmasarra, in: Al-Qantara 6 (1985) 503-506, on 504.

17 Cf. S. Stern, Ibn Masarra, Follower of Pseudo-Empedocles - an illusion, in: Actas del IV Congresso de estudos árabes e islâmicos, Coimbra-Lisboa, 1 a 8 de setembro de 1968 (Leiden 1971) 325-337, rep. in: Idem, Medieval Arabic and Hebrew Studies, ed. F. Zimmermann (London 1983) V. For Stern (326-327), Ibn Masarra "was a Sūfī, not Neoplatonic philosopher. There existed a 'school' of Ibn Masarra - but his followers, too, were Sufis, not Neo- 
with $b \bar{a}$ tini $i$ tendencies ${ }^{18}$, a follower (or the founder) of the so-called pseudo-Empedocles school ${ }^{19}$, a Fatimid missionary ${ }^{20}$, or a number of combinations of the above mentioned possibilities.

Ibn Masarra's own writings were considered as lost until 1972, when Muhammad Kamāl Ibrāhim Ja'far published two of his works ${ }^{21}$ : The Book of The Properties of Letters (Kitāb Khawäss al-hurū $f$ ) and The Epistle on Contemplation (Risālat al-itibār ${ }^{22}$. Ja'far's publication could have provided a basis for a less impressionistic evaluation of Ibn Masarra. But in fact, although two of Ibn Masarra's original works are now available, much of the scholarly discussion continues to ignore them ${ }^{23}$.

The difficulty in classifying Ibn Masarra is usually blamed on the scarcity of our sources. This impediment certainly exists, even after the publication of the two treatises. But the difficulty may, to some extent, be inherent to Ibn Masarra's thought, which does not lend itself easily to classification in the currently used molds, as well as to our own preconceived ideas.

Even a cursory examination of the two treatises published by Jafar reveals the peculiarity of Ibn Masarra's thought. The Epistle on Contemplation is in some ways reminiscent of the treatise known as "Pseudo-Jahiz", an early theological work of Christian origin, attributed to the Muslim theologian and literateur ${ }^{\circ} \mathrm{Amr}$

platonic philosophers. There were ....Neoplatonic philosophers in Spain ...- but they had nothing to do with Ibn Masarra and his school."; Makki, Ensayo 155-161 and especially 158, also regards Ibn Masarra as "the first real hispano-muslim mystic"; Ja:far, Min qadäya 1 192, sees his work as typically șūfī, as well as "a bāțini- Cabbalsitic style". Cruz-Hernández, on the other hand (Historia 346) insists on the absence of any typically sufi doctrine in Ibn Masarra's thought.

18 cf. Tornero, Noticia 49; Cruz-Hernández, Historia 346.

19 Asin, Abenmasarra, passim; Tornero, Nota sobre el pensamiento 504.

$20 \mathrm{Ja} f a r$, Min qadāyã 183.

21 Jáfar, "Min mu'allafät Ibn Masarra al-mafqūda, Majallat kulliyyat al-tarbiya," 3 (1972)

27-63 (non vidi); Ja'far, Min qadāyā 300-360. A new edition of Ibn Masarra's two works is currently being prepared by Sara Sviri and me.

22 This epistle is probably identical with the one entitled K. al-Tabsira; cf. Jaffar, qadāy $\bar{a}$ 300-306; idem, Min al-turäth al-falsafi li-ibn Masarra (Cairo 1982) 11-15. A third work of Ibn Masarra, The Monotheism of those Whose Knowledge is Certain (Tawbìd al-mūqininn), mentioned by Shams al-Din al-Qurțbī [d. 1173], is still not extant; Cf. Cruz-Hernándes, Historia 345.

23 Thus Arnaldez can still say in 1986 that none of Ibn Masarra's works has survived; cf. Ibn Masarra (note 7 above) on 869, col. 1. In 1996 Goodman (who cites Jaffar in his bibliography) can still say ("Ibn Masarrah", p. 279) that, "of his writings, only the titles survive". In 1993 and in 1998 Tornero thus justly felt the need to draw attention to the texts published 20 years earlier; cf. "Noticia sobre la publicación de obras inéditas de Ibn Masarra", in: Al-Qanțara 14 (1993) 47-64; idem, A Report on the Publication of Previously Unedited Works by Ibn Masarra, in: M. Fierro and J. Samsó (eds.), The Formation of al-Andalus, Pt. 2: Language, Religion, Culture and the Sciences (Aldeshot, Hampshire 1998) 133-150. De Smet (1998) refers to the texts only briefly, as an afterthought; see my review of his Empedocles Arabus in: Journal of the American Oriental Society 122 (2002) 94-97, on 95. 
b. Bahr al-Jähiz (d. 869)24. The bulk of Ibn Masarra's work is dedicated to the elaboration of the argument that the detailed contemplation ( $\left.i^{c} t i b \bar{a} r\right)$ of the world and of the marvels of nature indicates the existence of a wise creator. This is a basic tenet of the Mu'tazila, and in this sense, Ibn Masarra's Epistle can be seen as close to the world of Mu'tazili kaläm. But, despite the Epistle's name and the bulk of its content, Ibn Masarra's work goes beyond advocating the merits of contemplation. Its main thesis, presented from the outset, is the agreement of rational speculation and revelation, a thesis that is not formulated explicitly in the Pseudo-Jăhiz, and is not developed systematically by the Mutazila (although they would definitely concur with it). The Aristotelian philosophers (faläsifa) in the Orient are familiar with the thesis, but they, like the Mu'tazila, do not dwell on it continuously. Ibn Masarra's Epistle of Contemplation states this position in an unusually forceful and clear way ${ }^{25}$. Moreover, his pointed formulation of this thesis introduces a line of thought which was to gain a particular popularity among Andalusi Aristotelian philosophers, and which is attested in the writings of Ibn al-Sayyid al-Bațalyawsī and Ibn Tufayl, Averroes and Maimonides ${ }^{26}$.

But Ibn Masarra is not an Aristotelian philosopher, just as he is no mu tatzili theologian. Ibn Masarra's terminology and argumentations are often reminiscent of the Epistles of the Pure Brethren (Rasāill Ikbwān al-șafä). To cite just one conspicuous example, we may mention his frequent use of formulas such as: "May God guide us and you"27, a formula that has become almost a siboleth of the Epistles. In this context, it seems that Ibn Masarra's description in Muslim sources as ba atinin, a description which modern scholars have usually interpreted as referring to his esoteric mystical teaching, may in fact point to (or rather, also point to) possible influences of Fatimid Neo-Platonism, which at that precise moment was establishing itself in north Africa ${ }^{28}$.

The Epistle on Contemplation is thus an admixture of elements that, in the analysis of medieval Muslim texts, we usually identify as Mu'tazili, Aristotelian, or Neo-Platonist. Of course, we can argue that some of the elements are more conspicuous than others (although the balance of elements may vary from one paragraph to the other). Nevertheless, it would be misleading to impose on the

24 Cf. D. Z. Baneth, A Common source for Bahyā ibn Paqūida and al-Ghazālī, in: Magnes Volume (Jerusalem 1938) 23-30 (in Hebrew).

25 Ibn Masarra begins the Epistle by citing "one of the books" according to which "he who attempts to comprehend by contemplating the world, ascending from that which is below to that which is above, will find exactly what the prophets indicated, descending from that which is above to that which is below" (lā yajidu al-mustadrik mā (?) al-ítibär min asfal al'ālam ilā al-a 'lāillā mithla mā dallat alaybi al-anbiyā' min al-a'lā ilā al-asfal).

${ }^{26}$ For a discussion of some of these parallels, see Cf. Ja far, Min qadāya $159 \mathrm{ff}$.

27 E.g. "waffaqanā 'llāb wa-iyyāka" (Jáfar, Min qadāyā 348). Similar expressions appear also in the Book of Properties, e.g. "arshadanā 'lläb wa-iyyāka" (ibid. 322, 324).

28 The Fatimids conquered Kairouan in 910, whence they advanced until the conquest of Cairo in 969. Ibn Masarra has studied in Kairouan during the Fatimid reign, although the dates are not certain, see note 79 below. 
treatise a rigid classification, which obliterates the significance of the nuanced picture.

Ibn Masarra's other treatise, The Properties of Letters, corroborates this impression, although the admixture it offers is different. Only rarely can we see in it the marks of Mu'tazili influence, and distinctly Aristotelian elements are also infrequent. The predominant tone in the treatise discloses clear mystical and Neo-Platonist inclinations. The only Muslim author cited explicitly by Ibn Masarra is the ninth century mystic Sahl al-Tustāri (d. 896) ${ }^{29}$. The Neo-Platonism of Ibn Masarra's treatise is, however, closer to that of the Isma'îlī (Fatimid) brand than to rigorous Plotinian Neo-Platonism. The title of the treatise, which dwells on the "properties" of letters, suggests preoccupation with notions that, in other contexts, were often associated with alchemy and with magic practices. This branch of science flourished in al-Andalus and was favored by the Ismailis ${ }^{30}$.

Even a cursory reading of Ibn Masarra's two extant texts thus reveals the fact that the convenient classifications, to which we have become accustomed in the study of Muslim thought in the Orient, will not suffice here. We can, for sure, recognize the impact of the various schools of thought. But whatever Ibn Masarra's sources may have been, he mixed them in such a way that the outcome does not neatly fit any of the "schools".

To the extent that Ibn Masarra is indeed at the origin of Andalusian philosophical thinking, we must assume that the philosophical traditions he started would also follow patterns that are different from those adopted in the East. We must also bear in mind that the common language (Arabic), the common philosophical and scientific curriculum, and the shared libraries facilitated a closely-knit exchange between Jewish and Muslim intellectuals. This holds true regarding the Islamic world in general, but it is even more so in the Andalusi context, where the intellectual impact of the Christian community was relatively marginal in this period $^{31}$. A relative independence of Andalusi thinkers from eastern patterns should therefore be our working hypothesis, not only regarding Muslim thought, but also regarding Jewish philosophy and mysticism.

Students of Judaeo-Arabic philosophy are, of course, well aware of the tight links between it and its Muslim counterpart. For students of Muslim philosophy, however, the connection imposes itself less forcefully. The influence of the majority culture on minorities may indeed be less self-evident, and we tend to forget that dialogues and exchanges are, by definition, reciprocal. In the case of Ibn Mas-

29 Ibn Masarra cites several times from Sahl's Epistle on Letters (Risālat al-ḅurūf). This text

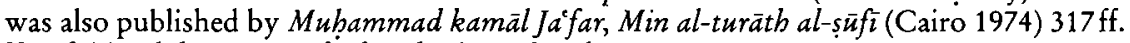

30 Cf. T. Fabd, s.v. Hurūf ( ${ }^{\mathrm{C}} \mathrm{lm}$ al-), in: $\mathrm{EI}^{2}$, vol. III 595-596.

31 On the relative intellectual weakness of the Christian community in al-Andalus in the early period, see, for instance, $D$. Urvoy, Pensers d'al-Andalus, la vie intellectuelle à Seville et Cordoue au temps des empires berbères (fin XIe siècle - débuts XIIIe siècle) (Toulouse 1990) 29, 33; Cf. Also B. F. Reilly, The Contest of Christian and Muslim Spain, 1031-1151 (Cambridge/Mass., Oxford 1992) 17-18. 
arra, however, the commonality cannot be ignored, since there are intriguing, and hitherto unnoticed, indications of the impact of Jewish thought on his work.

The possible presence of Jewish elements in Ibn Masarra's thought was suggested already by Asin Palacios, who drew attention to a passage in Muhyī al-Dīn Ibn 'Arabī's Meccan revelations. In this passage, according to Asín, Ibn 'Arabī (d. 1204) cited Ibn Masarra as saying that the four angels who carry the divine throne are in the form of a man, a lion, an eagle, and an ox. Asín pointed out the obvious dependence on Ezekiel, and on Jewish (and Christian) speculations on the Chariot $^{32}$.

Almost a century later, Miguel Cruz-Hernández and Emilio Tornero examined the extant texts of Ibn Masarra and pointed out the fact that such a description does not appear in his discussions of the divine throne ${ }^{33}$. The question then arises as to the source of the discrepancy: did Ibn 'Arabi impute to his predecessor a description that the latter never wrote, or did he have access to some other writings of Ibn Masarra, in which such a description did appear?

A closer look at Ibn 'Arabī's text, however, shows that Ibn 'Arabī does not really attribute such a description to Ibn Masarra. The text in question reads:

"As for the throne, which is the royal chair, God has angels who carry it on their shoulders. In our present day, they are four ${ }^{34} \ldots$. Regarding the forms of these four porters, things were said which seem to approximate the sayings of Ibn Masarra. For it was said that one [of the porters] is in the form of a man, the other in the form of a lion, the third in the form of an eagle, and the fourth in the form of an ox." 35

Ibn 'Arabi does not attribute the description of the porters to Ibn Masarra. He only says that this description is reminiscent of what Ibn Masarra had said. What Ibn Masarra did say is cited by Ibn 'Arabī a bit earlier, where he says:

"We were told that Ibn Masarra al-Jabali ... had said: The throne which they carry is the Dominion ${ }^{36}$. [The dominion] consists solely of body, spirit, sustenance and rank ${ }^{37}$. For Adam and Isräfîl are [in charge] of the forms ${ }^{38}$, Gabriel and Muhammad - in charge of the spirits, Michael and Abraham - in charge of liveli-

32 Cf. Asin 77 n. 13, who cites Munk, Mélanges 492. Asín himself (Abenmasarra 99, note 1) describes Ibn 'Arabï's imagery here as "algo cabalístico".

$33 \mathrm{Ibn}$ Masarra refers to the four angels in his Book on the Properties of Letters (Min Qadāya 340); cf. E. Tornero, A Report on the Publication 14; idem, Noticia 60.

34 The allusion is to the Qur'anic verse: "On that day, eight above them shall carry your Lord's throne" (Q. 69:17).

35 Al-futūhāàt al-makkiyya, ed. Uthmān Yabyā and Ibrābìm Madkūr (Cairo 1972) 355 (\#557).

36 Mulk.

37 As the following lines make clear, the "rank" refers to the position in the Hereafter.

38 "Forms" here in the sense of corporeal forms, the forms of the bodies. 
hoods, ${ }^{39}$ Mālik and Riḍān ${ }^{40}$ - of the retribution and reward. The Dominion contains only the things he has mentioned." 41

It is not very clear, in this passage, where exactly Ibn Masarra's words end and where Ibn 'Arabī's interpretation begins. Nevertheless, we can safely say that Ibn Masarra is referring to four categories of being as the carriers of the throne, and that either he himself or Ibn 'Arabī identify them with pairs of angels and prophets. Either way, we can see how Ibn 'Arabī regarded Ibn Masarra's statement as close to the description in Ezekiel, which he - not Ibn Masarra - had heard ${ }^{42}$.

The dissociation of Ibn Masarra from Ibn 'Arabîs description of the divine throne does not, however, put to rest the question of Ibn Masarra's Jewish contacts, since his own writings oblige us to raise it again.

The Book of the Properties of Letters belongs, according to its title, to the genre of letter speculation ${ }^{43}$. In the Introduction, however, it is presented by the author as a study of God's "beautiful names" (al-asmä al-busnā) and His attributes ${ }^{44}$. The two axes, of attributes and letters, are maintained throughout the book. At times, Ibn Masarra discusses the cosmogonic power of letters. On other occasions, Ibn Masarra identifies the letters with God's names, that is to say, His attributes. If we compare this book to the writings of a near contemporary, the Ismaili author Abū Hātim al-Rāzī, for instance, we will find that for the latter, in his Kitāb al-zina, God creates with the letters, and the letters are the archetype of the created things. On occasions, this is also the case of Ibn Masarra, who identifies some of the letters with the tools which God used in the process of creation (the pen, the ink, etc.). But mostly, for Ibn Masarra the letters are closely associated with God the creator Himself, since they are identified with His attributes. In this category, two passages deserve our attention.

The first passage discusses the four words of basmala, the opening formula of the Qur'ān:

39 Livelihood (rizq), as Ibn 'Arabi promptly explains in the following lines, is equal to sustenance $(\operatorname{ghad} h \bar{a})$.

40 One would have expected here another pair, of prophet and angel, rather than two angels. The natural candidate for the prophet in this pair would have been Jesus, whose Islamic image fits the eschatological phase. It seems, however, that the customary pairing of these two angels overruled the structure of the passage.

41 Al-Futūhāt al-makkiyya 348 (\#545).

42 Ibn 'Arabi could have heard this description in his youth in the Iberian peninsula, or later in Damascus, or anywhere else in his travels.

43 On this genre and the place of Ibn Masarra's work in it, see D. Gril, La science des lettres, in: M. Chodkiewicz (ed.), Ibn 'Arabī, Les Illuminations de La Mecque (Paris 1988) 412-436. 44 Purificación De la Torre (in her Introduction to Ibn Barrâ̄ān, Śarḅ asmä' Allāh al-ḅusnā [comentario sobre los nombres más bellos de dios] [Madrid 2000] 25-26) regards the $K$. alZìna by the Ismaili missionary Abū Hātim al-Rāzī (d. 933) as the first to combine God's names with letters. She considers al-Qushayrī (d.1072) to be the first șufī author to have written on God's names, and Ibn Hazm (d. 1064) as the first andalusi one. In all three categories, however, Ibn Masarra precedes these authors. 
“... Each one of God's names has ranks in its essence ${ }^{45}$, except the Greater Name, which encompasses the highest names and attributes.

... The other names have, in themselves, ranks, and there are grades in their essences. They are combined or separated for the sake of their reception by the created beings. They are either general or particular, according to their nobility, and they are either apparent or concealed, according to their subtleness, within the cluster of names ${ }^{46}$. The most general [cluster] is: 'In the Name of God, the merciful, the compassionate.' This is the first rank of knowledge, the highest and most noble one.

[This cluster] encompasses the subtleties of the Qur'an and the fine concepts thereof, because it is [composed of] the Hidden Name, by which God is truly known; of [the name of 47 ] Godhead, by which the generality of His names are known; of [the name] 'The Merciful', [by which] the division of His attributes is made apparent; and of [the name] 'The Compassionate' [by which] their apparent nature and their specificities are made clear according to [their] degrees."48

"The hidden name by which God is truly known" is understood by the editor of the text, Ja'far, as identical with the word God (Allab). This seems indeed the most natural way to understand the expression in a Muslim text ${ }^{49}$. The context, however, makes it clear that the Hidden Name (al-ism al-mudmar), the ineffable name of God, is the very word "name" (ism). In Sunni Islam, "there have never been observed a taboo respecting the name of God" 50 , that is to say, no reticence to pronounce it. But the idea of an ineffable name, which is above all other names, is quite common in Shiite sources ${ }^{51}$. In none of these sources, as far as I know, does the word "name" become this ineffable name. One is inevitably reminded here of the Jewish custom to substitute the name of God (and not only the Tetragrammaton) with the word "the Name" (ba-Shem) $)^{52}$.

Following the discussion of the basmala, the next "cluster" to be discussed is the opening süra of the Qur'ān, the fätiba, which according to Ibn Masarra con-

45 "La-bu fi dhätibi marātib." This could indicate an inner division of each name, but also the fact that each name has its own rank.

$46 \mathrm{Jaw} \vec{a} m i^{e}$ al-asmä, i.e., clusters rather than each one on its own.

47 The structure changes here abruptly, although the text probably intends to offer a parallel analysis for the four names. Thus we should either understand the text as if it says: "wa-min $X$, allädbi bi-bi..." (as suggested above); or omit the words "by which..." (alla dbi bi-bi) in the first sentence, and translate: "because from the hidden name-God is made truly known" etc.

48 Cf. Jaefar, Min qadiayā 313-314; D, fols. 132-133.

49 According to Gimaret (who cites al-Baghdādi), this is also the most common Sunni identification; cf., D. Gimaret, Les noms divins en islam (Paris 1988) 89-90, and see below, note 64. 50 F. M. Denny, Names and Naming, in: The Encyclopedia of Religion, vol. 10, ed. M. Eliade (New York, London 1987) 302.

51 See G. Vajda, Les lettres et les sons de la langue arabe d'après Abū Hātim al-Rāzī, in: Arabica 8 (1961) 113-130, on 124; Gimaret, Noms divins 88.

52 Cf. Art. God, Names of, in: R.J. Zwi Werblowesky and G. Wigoder (eds.), The Oxford Dictionary of the Jewish Religion (New York, Oxford 1997) 278; and see also Gimaret, Noms divins 86, regarding the impact of isrä iliyyāt on the preoccupation with the Ineffable Name. 
tains twelve divine names ${ }^{53}$. He then declares his intention to move on to the discussion of the fawatib ${ }^{54}$, the fourteen "mysterious letters" that appear at the beginning of 29 Quranic chapters ${ }^{55}$. According to Ibn Masarra, these letters reveal the inner meaning (bātin) of the Quranic revelation. These letters are indeed the subject of most of the remaining part of the treatise. The remaining fourteen letters of the Arabic alphabet, which reveal its exterior meaning (zābir), are not discussed in it.

The letter alif is granted a separate discussion, as the first letter of the Alphabet ${ }^{56}$. Thereafter Ibn Masarra discusses the letters in clusters, and as a rule, he groups them as they appear at the beginnings of the Quranic chapters. The first cluster, however, is the only cluster that does not follow this rule. It treats five letters: $h \vec{a}$, hamza, alif, waw, and $y \vec{a} 57$. One should first of all note the puzzling inclusion of the letter waw, which does not belong in the fawatib at all58. The other four letters do belong in the farwātih, but in the Qur'ān they are not grouped together but rather with other letters. We must therefore look for another reason for their treatment as a group ${ }^{59}$, but such a reason is not easily found. Three of the letters are the mater lectionis, but the fourth $(b \vec{a})$ is not considered to belong in this category in Arabic, and indeed Ibn Masarra himself explicitly says that the number of mater lectionis is three ${ }^{60}$. In some șüfī works, the letter $\vec{b} \vec{a}$ is discussed in the context of respiration techniques and of the origin of the letters in the various locations of the vocal tracts ${ }^{61}$. Such considerations, however, are treated separately by Ibn Masarra, and the letter $b \vec{a}^{3}$ does not appear there ${ }^{62}$. In the Muslim/ Quranic and Arabic context this cluster thus remains unexplained. In a Jewish and

53 Cf. Jáfar, Min qadāyāa 315.

${ }^{54} \mathrm{Cf} . J a^{e} \mathrm{far}, \mathrm{Min}$ qad̄aya $316 \mathrm{ff}$. As the analysis of the fawatib forms the bulk of the treatise, one wonders whether the preceding discussion of the fätiba may not be an afterthought, by association, due to the similarity of the Arabic term.

55 On the "mysterious letters," see $A$. T. Welch, s.v. "al-Kurän", in $\mathrm{EI}^{2}$, vol. V 412-414.

56 Cf. Ja'far, Min qadāyā 319-322.

57 Cf. Jáfar, Min qad̄āya 322-323.

58 This oddity was noted already by Tornero, Noticia note 20.

59 Although according to Ibn Masarra's previous declaration, the subject of the discussion is indeed the mysterious letters.

$60 \mathrm{Cf}$. Jáfar, Min qadāya 320 . The alif-waw-yā' appear also in Dünash Ben Tamīm's Commentary on Sefer Yeżira; cf. G. Vajda, Le Commentaire sur le Livre de la Création de Dūnaš ben Tāmìn de Kairouan (Xe siècle), Nouvelle édition revue et augmenté par Paul B. Fenton (Paris 2002; henceforward: Le Commentaire sur le Livre de la Création) 225-226 (text), and 80-81 (translation); in Hebrew, however, the letter be can be considered in the category of mater lectionis; see, for instance, Le Commentaire sur le Livre de la Création, ibid.; Qirqisānī, Kitäb al-Anwār wa'l marāqib, II 23.8 (164 in Nemoy's edition), as complemented by $B$. Chiesa, Il fenomeno del ketiv-qe $\gamma^{e}$ secondo Yáqūb al-Qirqisānī (ca. 927 d. C.), in: L. Cagni (ed.), Biblica et Semitica - Studi in memoria de Francesco Vattioni (Napoli 1999) 81-94, on 93 (where Qirqisān̄i discusses the letters חוּ); cf. also Abū Hātim al-Rāzī’s K. al-ẓinna (Vajda, Les lettres 115-116).

61 Makhārij, cf., for instance, L. Massignon, La passion d'al-Hallāj, vol. I 105; Vajda, Le Commentaire sur le Livre de la Création 84-89.

62 See below. 
Hebrew context, on the other hand, an explanation for this combination of letters readily suggests itself, as it reflects the Tetragrammaton (yod be vav be) ${ }^{63}$ and its verbal expression as it appears in Ex. 3:14 (aleph he yod he).

If this explanation is accepted, one would expect the letter $h e / b \vec{a}^{3}$ to gain particular importance, and indeed Ibn Masarra states it explicitly, saying: "The $h \vec{a}$ ” indicates the Essence", a clear allusion to the third person pronominal noun " $\mathrm{He}$ " ( $h \bar{u} / h u w a)$ and to its functioning (in both Hebrew and Arabic) as a linking copula ("He is"). Ibn Masarra's statement is in line with his previous reference to "the Name" as God's ineffable Name ${ }^{64}$.

Of particular interest is the immediately following discussion of the letter alif, which is closely associated with the hamza.

"The alif itself is of three ranks: a rational soul, an animal soul, and a vegetative soul.

It has been said that the hamza is the intellect, which is the Will; the alif is the rational soul; the waw is the animal soul; and the $y \vec{a}$ is the vegetative soul.

The alif is upright, the $y \vec{a}$ is prostrating, and the waw is bowing down. This is why you find in creation these three animate forces. The living being which has a rational soul is upright, like the alif. That which has only an animal soul is kneeling, bowing down like the waw. That which has a vegetative soul is prostrating with [all] its body, for its head is only near the earth, like all plants." 65

Because of the close association of alif with hamza, Ibn Masarra can tie the alif up with waw and $y \vec{a}$, the two other letters which, like the alif, serve as a graphic support (kurst) for the hamza. He assigns each of the three letters a place in the hierarchy of souls (rational, animal and vegetal). Such a comparison of these three letters with the three souls can be found in other Muslim texts ${ }^{66}$. Ibn Masarra also claims that the hierarchy is reflected in the very form of these letters. One can see how the graphic form of these Arabic letters may be used to justify Ibn Masarra's interpretation. What remains unexplained, however, is Ibn Masarra's puzzling statement that "The alif itself is of three ranks"67. The single stroke which constitutes the Arabic alif renders this statement unintelligible. In this case (as in the case

63 The three "simple" letters are associated with the Tetragrammaton in Sefer Yezira, I, 13. The text identifies the three as he, vav, yod; cf. Saadia' al-Fayyumī, Commentary on the Book of Creation (kitāb al-mabädi), ed. Y. Qafih (Jerusalem 1972) 126. Dūnash, however, makes a point of identifying them with the three vowel letters (aleph, vav, yod), and then explains the relevance of the be; cf. Le Commentaire sur le Livre de la Création 225-226 (text), 80-81 (translation). See also Y. Liebes, Ars Poetica in Sefer Yetsira (Jerusalem 2000) 217-245 (in Hebrew) 19, 177.

64 Although in another passage (Cf.Ja far, Min qadāyā 325) Ibn Masarra speaks of the letters alif-lam-mim as "the pre-eternal, everlasting name, which cannot be made explicit more clearly than by saying "He is'”. The identification of alif-lam-mim as "the Greater Name of God" (which is not necessarily the ineffable name) is indeed quite common in Muslim texts, see Gimaret, Noms divins 88 and note 8.

65 Cf. Já far, Min qad̄àa $322-323$; D fol. 140.

$66 \mathrm{It}$ is also found in al-Tustārî's Epistle on Letters 369.

67 "Al-alif $f_{i}$ nasfíba a thalāth marätib." 
of the cluster as a whole), the Hebrew parallel (i.e., aleph, which is written in three strokes) offers a natural context in which such a statement could be made intelligible 68 . As mentioned above, the "kneeling" and "bowing down" positions can be justified also as reflections of the forms of the Arabic letters. But since in Ibn Masarra's text this development follows from the opening statement, about the three stages of the alif, it stands to reason to assume that the whole paragraph is inspired by the same source.

This source, I submit, must have been a Jewish speculation on the form and meaning of the Hebrew alphabet. It is noteworthy that a Jewish text in which the letters are discussed in the same way, the Book of Creation (Sefer Yezira) has become immensely popular in the tenth century, as attested by the proliferation of commentaries on it $^{69}$. At least one such Commentary was written in Kairouan, around the same period when Ibn Masarra passed through this city ${ }^{70}$.

Perhaps the clearest support for this claim can be found in the first lines of Ibn Masarra's Book of Properties of Letters.

"[God] has sent down His book ... He, may He be exalted, sent it down as one from His perspective, divided from the perspective of His creatures. It is thus one complex as regards His essence, [but] divided to three complexes from the perspective of His creatures. The first complex is the science of divinity (rubuibiya); [The second is] the science of prophecy;... and [finally] the science of trial (mibna)."71

The tripartite nature of the one book with which (as the treatise shows later) God created his world, is reminiscent of the three books mentioned in the first lines of Sefer Yezira ("God created His world with three books [sefarim]: sfar, sippur and sefer"). While the role of the three books in the two texts is developed in different ways, the similarity of the tripartite paradigm of the single book is striking.

68 Later Jewish texts also develop the idea, saying that the graphic form of the aleph encompasses a "kneeling" yod and a "bowing down" vav. I am indebted to Paul Fenton for drawing my attention to these developments. Another aspect of the triple phonetic character of the aleph is alluded to by the Midrash Alpha Beta de-Rabbi Aqiva, ed. A. Jellinek, Bet haMidrash III (Jerusalem 19673) 17 ("why is aleph written as one letter, and read as three"). The resemblance of the teaching of this midrash to the Book of Creation is noted by Liebes, Ars Poetica 178-179.

69 On the debated question of the date of composition of Sefer Yezira, see, for instance, S. $M$. Wasserstrom, Sefer Yezira and Early Islam, a Reappraisal, in: Journal of Jewish Thought and Philosophy 3 (1993) 1-30; Liebes, Ars Poetica 217-245. On the early medieval Commentaries, see: $R$. Jospe, Early Philosophical Commentaries on the Sefer Yezira: Some Comments, in: Revue des études juives CXLIX (1990) 369-415; M. Idel, Jewish Thought in Medieval Spain, in: H. Beinart (ed.), The Sephardi Legacy, Vol. I (Jerusalem 1992) 261-281, on 263-264.

70 Cf. Fenton's Introduction to Le Commentaire sur le Livre de la Création 10-20; and see note 78 below.

71 Jáfar, Min qadāya 311-312; D, fols. 130-131. The last complex is associated with the retribution in the Hereafter, and thus corresponds to the legal aspect of religion. The term "trial" for this complex may have antinomian undertones. 
The similarity becomes even more striking when one considers the commentary on this passage, included in Judah Ha-Levi's Kuzari:

"Sefer Yezira ... which indicates God's unity and His divinity by different things, which are multiple from one aspect, but agree and are one from another. Among them are sfar, sippur and sefer... the sfar, sippur and sefer are one thing from the point of view of God, and three from the point of view of the human being. ... He created His world with three books, all three of which are one from His perpspective."72

Like Ibn Masarra, Judah ha-Levi (d. 1141) insists on the fact that the books with which God created His world are three only from the human perspective, but one from the divine perspective. The possibility that the similarity of the two texts results from a mere coincidence cannot be ruled out, but it seems to me very unlikely. It is quite possible that ha-Levi was familiar with Ibn Masarra's work. But the most likely explanation for the similarity in this case is an earlier Commentary on Sefer Yezira which inspired both Ibn Masarra and ha-Levi.

Ibn Masarra's interest in Judaism is, in fact, reflected in his own words, in his discussion of the cluster alif-lam-rä . After stating that there are six occurrences of this cluster in the Qur'ān, which correspond to the six days of creation, Ibn Masarra adds:

"And the seventh day is the day of rest and completion. For this reason the Jews made it a Sabbath, that is to say, they rested."

Unlike in the Hebrew Bible, the Quraanic treatment of the six days of creation does not refer to God's resting on the seventh day. ${ }^{74}$ Nor does the Qurān specify in the context of creation the name of the seventh day as "yawm al-sabt"75. The association of the six days of creation with the seventh day of resting, and with the name of this seventh day, thus triggers an immediate association with the Jewish Sabbath and the Hebrew etymology of the word. Ibn Masarra could, no doubt, have found the etymology in Muslim sources, which had already processed and integrated such information via earlier Jewish traditions (isrä'iliyyāt). But one should note the fact that nothing in the discussion of the letters in this cluster requires a mention of the seventh day at all, let alone an elaboration on its meaning. The whole sentence is a rather uncharacteristic digression on Ibn Masarra's part, a digression that suggests preoccupation with things Jewish. Moreover, the use here of the name $y a b \bar{u} d$ (rather than a Quranic term such as bani $i s r \bar{a} \bar{\imath} l$ ) seems

72 Kuzari 4:25; cf. D. H. Baneth and H. Ben-Shammai (eds.), Kitäb al-Radd wa'l-Dalïl fìlDìn al-Dhalìl (al-kitāb al-Khazarī) (Jerusalem 1977) 174-175.

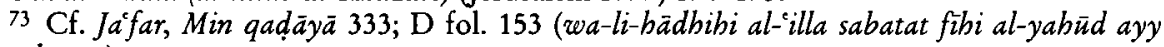
sakanat).

74 In fact, the Qur'ān rejects explicitly the idea that God should rest: cf. Q. L:38; and see A. Rippin, s.v. Sabt, in: $\mathrm{EI}^{2}$, Vol. VIII 689.

75 Although the name does appear in the Qur'ān as the day of resting, imposed on the Jews on Mt. Sinai. Cf. Q. IV:154. It also mentions the breaking of the Sabbath, and the punishment thereof, cf. Q. II: 65 ; IV:47, VII:163; XVI:163. In all these verses, the name yabū does not appear, and the context speaks of "people of the book" or people associated with the prophets Moses and Abraham. 
to indicate that Ibn Masarra does not intend this digression as an exegetical observation. Ibn Masarra's train of thought, which leads him to associate the days of creation with the Jewish Sabbath, suggests an acquaintance with contemporary Jews, with whose ways of life (and the theological explanation thereof) Ibn Masarra seems to have been familiar.

If we accept the claim that Ibn Masarra's work includes some Jewish elements, there are several possibilities to explain their presence:

One may point to the existence of Jewish influence on Islam in its formative period, and to the connections between Jews and Muslims in the Orient. The existence of some such connections and such influences are accepted by most contemporary scholars, and hardly need any proof. It can be argued that Muslim books and Muslim travelers transmitted these ideas to al-Andalus.

But the nature of the Jewish elements in Ibn Masarra's work, as well as the circumstances of his life, seem to me to favor the possibility that he also had direct contact with Jewish scholars. As mentioned above, Ibn Masarra was known as "a $b \bar{a} t i n \bar{\imath}$ ", who spent some time in the already Fatimid North Africa. At the beginning of the tenth century, this region seems to have been a hotbed of new developments in Neo-Platonic thought, and Ibn Masarra's writings, as noted above, bear the mark of Fatimid Neo-Platonism. In this context, one should mention the question-marks regarding the Jewish-Ismaili milieu in North Africa ${ }^{76}$. A particularly telling illustration of the role of Jews in the transmission of philosophy in this milieu can be found in the autobiography of Ibn al-Haytham, an Ismaili missionary from Kairouan who was also sent to al-Andalus. Born to a respectable Shii family, Ibn al-Haytham received traditional Islamic instruction from several teachers. In the field of logic, however, his sole instructor was an otherwise unknown Jew named Yūsuf ibn Yahyāa al-Khurāsān̄in, with whom he studied in Kairouan $^{77}$. It is also in Kairouan that Isaac Israeli, the court physician of the first Fatimid caliph, 'Abdallāh al-Mahdī (d. 955) wrote his Commentary on Sefer Yezira ${ }^{78}$. Ibn Masarra had spent some time in Kairouan during the same period. ${ }^{79}$

76 Cf. P. B. Fenton, The Arabic and Hebrew Version of the Theology of Aristotle, in: $J$. Kraye and others (eds.), Pseudo Aristotle in the Middle Ages (London 1986) 241-264.

77 Cf. W. Madelung and P. E. Walker, The Advent of the Fatimids - A Contemporary Shi i Witness (London 2001) 52, 60, 112. On the Jews of Kairouan, see M. Ben Sasson, The Emergence of the Local Jewish Communities in the Muslim World: Qayrawan, 800-1057 (Jerusalem 1996, in Hebrew) especially 250-252.

78 On Isaac Israeli, see A. Altmann and S. M. Stern, Isaac Israeli: A Neoplatonic Philosopher of the Early Tenth Century (Oxford 1958); Fenton, Introduction 3-6. The Commentary of Isaac Israeli is not extant, but we may safely assume that the one written by his student Dünash ben Tamim reflects the school tradition. Isaac Israeli came to Kairouan to serve as the court physician of the last Aghlabid ruler, whose reign ended in 909 , and he stayed to serve 'Abdallāh al-Mahdī. From Kairouan, he exchanged letters with Saadia Gaon on philosophical topics, before the latter left Egypt in 915 (cf. Fenton, Introduction 11). Although we do not know the date of the composition of Israeli's Commentary, these early discussions, mentioned by Dūnash in his Commentary on Sefer Yezira, may well have touched on this book. 79 The information regarding Ibn Masarra indicates that he stayed in Kairouan either before 920 (according to Ibn 'Idhārī, who says that he studied in Kairouan with the faqīh A ḥmad 
The possibility that Ibn Masarra's writing of a similar speculation on letters is a mere coincidence seems to me to be highly unlikely.

We can now return to our starting point, namely, the role of Ibn Masarra in the development of mysticism in the Iberian peninsula. The Influence of Ibn Masarra on subsequent Muslim mysticism is generally recognized ${ }^{80}$. It is now time to take him into consideration also in the study of Jewish and Christian mysticism. By way of an example, we may mention the claim that "the first philosophical writings in Spain betray a relative lack of interest in Sefer Yezirab in comparison to the central place this book occupied in the Orient" and that "it was only a non-philosophical writer, R. Judah al-Bargeloni, who undertook a full-scale exegesis"81. In view of its apparent impact on the first Muslim philosopher of Spain, this statement must now be qualified. On the one hand, Ibn Masarra provides the evidence that there was no lack of interest in Sefer Yezira. On the other hand, Ibn Masarra was not only a Muslim, but also a Muslim whose name acquired a dubious reputation among the ruling Muslim Sunnis in al-Andalus ${ }^{82}$. If Jews in al-Andalus were familiar with Ibn Masarra's letter-speculation (regardless of whether or not they also realized the impact that Sefer Yezira had on him), this in itself may have caused some reticence on their part to focus on such speculation in their writings.

It is ironic that Asín, who played such a central role in propagating the idea of a Pseudo-Empedoclean "school of Ibn Masarra", begins his book on Ibn Masarra with the statement that all Spanish philosophy comes from the Orient. "PseudoEmpedocles" is perhaps the most Spanish story in the history of Islamic philosophy: all of its main characters are Spanish, and many of them are Jews. Indeed, one can say with certainty that Jewish thinkers played an active role in the formation and fermentation of Andalusi neo-Platonism, in its more philosophical as well as in its more mystical versions. In evaluating the parallelism of Jewish and Muslim texts from this period, Georges Vajda (who, in this context, carefully tried to avoid the claim of any influence in any direction), summed it up:

ibn Nașār b. Ziyād [d. 920]; cf. I ļsān 'Abbās (ed.), Ibn Tdhārī al-Marrākushī, Al-Bayān alMughrib fi akbbār al-andalus wa'l-maghrib (Beirut 1967), or not later than 912 (cf. Stern, A propos de l'ascète).

80 See, for instance, Gril, La Science des lettres; C. Addas, Quest for the Red Sulphur: The Life of Ibn Arabī, translated From the French by P. Kingsley (Cambridge 1993) 58. The study of Ibn Masarra's own works should provide more information for the evaluation of his influence.

81 Cf. Idel, Jewish Thought in Medieval Spain 264.

82 On the persecution of "the Masarris," see $M$. Cruz-Hernández, La persecusión anti masarrī durante el reinado de 'Abd al-Raḥmān al-Nāṣir li-dīn Allāh segun Ibn Hayyān, in: AlQanțara 2 (1981) 51-67; 3 (1983) 482-483. The date of the persecution (after 961, that is to say, long after Ibn Masarra's death) as well as its description by the historiographers, suggest its reason or at least its context. The threat of the rising Fatimid power seems to have heightened the ruling Umayyad sensitivity to battini ideas (and not the other way round: that the Masarrīs have used Fatimid notions against the mālikis; cf. Fierro, Los Mālikies 93, note 62). The Umayyad's Jewish subjects were probably well aware of this sensitivity, an awareness that might have effected their literary output. 
"Il y a du moins, malgré toutes les divergences, une similitude de climat qui suppose, croyons-nous, un fonds commun de gnosticisme ${ }^{83}$.»

It seems to me that one can be more affirmative. Despite all the differences, and although one cannot draw a continuous line that describes the direction of development and transmission, there is a similarity of atmosphere which presupposes a common ground of ideas, nourished by direct contacts between Muslims (both Sunnis and Isma'ili Sh'iis) and Jews. These contacts allowed for the free flow of ideas in both directions. Ibn Masarra, "the first Spanish-born thinker" introduced this atmosphere to al-Andalus, making it into the first manifestation of mystical thought in the Iberian peninsula.

83 Les lettres 125. 